\title{
The Development of Black Refugee Identity in Nova Scotia, 1813-1850
}

\section{Harvey Amani Whitfield}

In 1841, former American slaves and their descendants celebrated the birth of the future Edward VII. The membership of the African Friendly Society, its "most loyal subjects," hailed British liberty and reminded the public that they "enjoyed the blessings of a wise and enlightened government.... We feel, in the highest degree, sensible of the gratitude and faithful attachment, which We owe to your August person and government." Two years later, at the New Year's African Jubilee, the African Constitution Society toasted both the Queen and Prince Albert, and thanked "Wilberforce - the friend and benefactor of the African race, who by his philanthropy has conferred the blessings of emancipation upon the slave, who no longer writhes under the taskmaster."2 These connections to Britain and British personalities is indicative of an emerging African British North American identity, which placed emphasis on black peoples' associations with the Crown while acknowledging their geographical location in the Empire. The African British North American identity in Nova Scotia was not limited, in the sense that it included aspects of a genuine Pan-African consciousness, a consciousness also found among free black communities in the United States who annually celebrated "our brethren set at liberty in the British West India Islands." 3 These examples are illustrative of the transformation of several slave identities into an African British North American identity that flourished among Black Refugees in Nova Scotia after the War of 1812.

This paper seeks to understand the construction of an African British North American identity out of various slave backgrounds and experiences. This complicated process is a study of transnational African American history that adheres to the statement of Robert Harris that "the web of Afro-American history radiates beyond the United States borders. It exists within the core of two intersecting circles, one in this country and the other in the African World."4 Attentive to this paradigm and the work of Robin Kelley and Earl Lewis concerning black history's global vision and its place within overlapping diasporas, this essay is about the movement of the Black Refugees from two points in the Black Atlantic: the Lowcountry and the Chesapeake, to Nova Scotia. 5 The transition from slave identities to an African British North American consciousness can be understood through an examination of the Black Refugees' early settlement patterns and the political and cultural dimensions of this emerging consciousness. Studying the development of Black Refugee identity builds on previous works, which focus on the economic and social struggles of these

9

(C) Left History

10.2 (Fall 2005) 
American migrants. In highlighting identity formation, this paper examines a dimension of the black experience in Nova Scotia that might open up other avenues for understanding the richly textured history of former American slaves in British North America. Before embarking on a discussion of these topics, it is beneficial to examine the context that the Refugees found in Nova Scotia after the War of $1812 .^{6}$

It is sensible to divide the history of in-migration to Nova Scotia into two distinct periods; one before 1776 and the other after 1783. Before the American Revolution, the actual population of people of African descent did not exceed 300 people at any one time. Yet, this small population connected Nova Scotia to the wider currents of Black Atlantic history. The African presence in Nova Scotia probably began with a free African named Mathieu Da Costa, who had been contracted by the French to serve as an interpreter at Port-Royal to facilitate trade with the Mi'kmaq during the early seventeenth century. During the rest of the seventeenth century, the sparse records indicate that a few Africans entered Nova Scotia, but their stories are shrouded in mystery. Nova Scotia's first substantial encounter with people of African descent occurred during the early eighteenth century. This encounter was forged in a context of inequality as less than 300 black slaves worked for various owners in the French stronghold of Ile Royale in present-day Cape Breton. These slaves "were multilingual and came from the West Indies, Africa [including Benin, Congo, Guinea, and Senegal], India, France, Canada, and the British American colonies." 8 Generally, they worked as domestics and had much in common with slaves in the New England colonies. After 1713, mainland Nova Scotia became part of the British Empire. The number of Africans in mid-eighteenth-century English Nova Scotia was quite small, but significantly, the urban center of Halifax traded slaves with Boston and New York. Moreover, the settlement of the New England planters in Nova Scotia between 1760 and 1774 brought several black slaves to the colony. ${ }^{9}$ The importance of Nova Scotia's small slave population cannot be found in its contribution to the local economy, but rather in its affect on general attitudes toward people of African descent, whether they were enslaved or free. As historian James Walker notes, "in a society conditioned to thinking of blacks as slaves, the claims of the free black loyalists for equality were not always to be taken seriously." 10 The use of people of African descent in this early period as a captive and cheap labour force dictated policies toward subsequent immigrations of black people.

After the American Revolution, two significant groups of black immigrants, the Black Loyalists and Jamaican Maroons, settled in Nova Scotia. Some of the Black Loyalists and nearly all of the Jamaican Maroons left the colony in disgust after short periods of settlement. During the American War, the British offered freedom to slaves willing to desert their rebel owners. As a result, 3500 Black Loyalists escaped their owners and headed to Nova Scotia 
via the Royal Navy in 1783. This total number does not include the hundreds of slaves brought north by white Loyalists. In a short period, a colony with likely only 200 people of African descent suddenly acquired thousands of African Americans. Although they had been promised land and meaningful freedom, the Black Loyalists found neither in Nova Scotia. Many of the new black settlers received no land, or very small allotments. As a result, the new migrants had to search for town work. Black Loyalists were hired at lower wages than the local white labouring population, which caused an outbreak of racial violence in 1784 . Yet, it should be noted that this outbreak of violence had labour overtones that might have been as important as racial differences. During the early 1790 s, British abolitionist John Clarkson commented that it "is not in my power to describe the scandalous and shameful conduct shewn to the free Blacks by many of the White people." As a result of this "conduct," about 1200 Black Loyalists left Nova Scotia for Sierra Leone in 1793." Three years later, the imperial government deported the Jamaican Maroons to Nova Scotia in 1796 to secure the property of slaveholders and quash resistance to the local regime. This immigration of 500 people of African descent proved to be disastrous. The Maroons resented the colony's attempt to use them as a cheap labour force and rejected the local government's attempt to introduce them to Christianity and end their polygamous lifestyle. In 1800 , less than five years after their arrival, nearly all of the Maroons migrated to Sierra Leone. ${ }^{12}$

Nova Scotia's experience with black immigrants during the late eighteenth century affected the Refugees from the War of 1812. First, local officials and the general population believed that people of African descent were "unfitted by nature to this climate, or an association with the rest of His Majesty's colonists." 13 The colonial government wanted to use the Black Refugees as a semi-captive and cheap labour force as they had attempted to do with the Black Loyalists and Jamaican Maroons, a factor that had played a role in these groups migrating out of the colony. Moreover, the Black Loyalists and Jamaican Maroon exoduses convinced the local white population that black settlers did not deserve land grants because they would inevitably leave the colony and waste any money the government spent on them. This belief resulted in local officials creating land policies that ensured that black settlers would subsist not as owners of land, but as squatters in constant need of menial employment. One local resident encouraged the settlement of blacks in his neighborhood for they would "furnish us with Laborers of whom we stand in too much need to make any tolerable progress in our own improvements." ${ }^{14}$ Second, the perceived failure of previous black immigrants led many to the conclusion that Africans were only fit for slavery, despite the fact that the colony had begun to phase out the institution in the early $1800 \mathrm{~s}$, as Africans did not understand the so-called "reward of labour."15 The African Americans who immigrated to Nova Scotia after the War of 1812, regardless of their vastly different experiences and array 
of occupational talents, encountered a host population that considered blacks to be a drain on the colonial treasury.

The Black Refugees emerged from at least two distinct cultures of slavery. The majority of the 1600 African Americans who landed in Nova Scotia originated from the Tidewater Chesapeake and the Georgia Sea Islands. ${ }^{16}$ The Chesapeake Refugees' experience with American slavery differed from their counterparts in the Sea Islands. They worked on small to mid-sized farms with only a few other slaves, usually less than twenty, under the close supervision of owners or overseers. Although some still hoed tobacco, as a result of the European wars of the late eighteenth and early nineteenth centuries, most slaves worked in mixed agricultural production. This switch to various types of agricultural production markedly increased the labour required of Chesapeake slaves. In contrast, the Sea Island Refugees worked on large rice and cotton producing plantations with hundreds of other slaves. The expansion of rice and cotton production in the late eighteenth and early nineteenth centuries resulted in arduous and unhealthy labour that made slave mortality rates quite high. The Sea Island Refugees laboured under the task system, which required them to complete a given daily assignment. However, once completed, slaves usually had the rest of the day to do as they pleased. In terms of social life and culture, some Chesapeake Refugees had adopted Christianity and had more contact with Anglo-American culture than the Sea Island Refugees, who "remained physically separated and psychologically estranged from the Anglo-American world." "1 The American slaves who would become Black Refugees developed in two vastly distinct slave systems. ${ }^{18}$

The Black Refugees' escape from the United States is an oft-told story that can be understood as a conscious rebellion against American slavery. Although many African Americans absconded after Admiral Cochrane's April 1814 proclamation offering freedom and subsequent settlement in the British colonies, the Refugees initiated this policy by escaping to Royal Navy ships before 1814. This is evidenced by the 133 Black Refugees who entered Nova Scotia in September of 1813. Moreover, the escape of thousands of African Americans cannot be painted as the British giving freedom to idle blacks, who could only have been convinced to leave their owners because of elaborate promises of an easy post-emancipation life with pretty houses and marvelous carriages under the benevolent rule of the supposedly black queen of England. Instead, the Black Refugees claimed their own freedom by fighting for the British, sabotaging American operations, and becoming a veritable fifth column that struck fear into the highest levels of the US government. In short, the Refugee rebellion took advantage of British military necessity to gain freedom. ${ }^{19}$

The Black Refugees brought many aspects of their work experience to Nova Scotia. Yet this transfer of labour experience was uneven. Among the 
fortunate ones were Refugees trained in certain occupational skills, such as carpentry, that helped them find work in Nova Scotia. Due to their closeness to water in the Chesapeake and the Sea Islands, many Refugees had experience working on boats and found employment in Nova Scotia's docks and shipping industry. In contrast, those Refugees who had been employed as rice and cotton workers in the Sea Islands could not use these skills on their farms in Nova Scotia, which required breaking stones and cutting down trees to grow potatoes. Perhaps the most significant work experience brought to Nova Scotia was the transfer of market trading skills that provided the Refugees with a substantial source of income. Although the Refugees brought different work experiences to Nova Scotia, depending on gender, plantation, and geographic location (rural or urban), the British imperial government assumed that all had been farm labourers. As a result, imperial and local officials expected men and women of different skill levels to become subsistence frontier farmers even if they had been domestic servants their entire lives. ${ }^{20}$

The Black Refugees also brought one significant cultural aspect of their American background to Nova Scotia. The experience of separate black places of worship, though they had existed in Nova Scotia before the Refugees' arrival, held out an important ideal that the migrants continued in their new home. Indeed, forms of Afro-American Christianity prevalent in the Chesapeake generally, and Virginia in particular, would be reproduced in Nova Scotia. Other aspects of slave life, such as extended family and kinship ties, took on added importance as many households contained several family members ranging from the newborn to the elderly. During slavery, the Refugees had been mutually reliant and supportive of one another. This trait continued in Nova Scotia as the more fortunate Refugees continually fed, housed, and cared for the poorer members of the emerging communities. The importance of the church and family structure would form the building blocks of the Black Refugee community in the nineteenth century.

The Black Refugees entertained high hopes for freedom in Nova Scotia. According to Charles Ball, who traveled with his master to the British ships to beg his counterparts to return home, the Refugees wanted land and freedom. ${ }^{21}$ Another observer of the Black Refugees, a British soldier, commented that they only wanted liberty. ${ }^{22}$ The ideal of freedom entailed several different hopes. For example, some Refugees had been torn apart from their wives or husbands during slavery and impending freedom in Nova Scotia ended this separation. In the late 1880 s, one Refugee recalled that the fear their former owner would sell friends and family members away from Virginia provided the impetus for him and others to abscond. ${ }^{23}$ The Refugees wanted freedom, land, and family stability that would not be subjected to the vagaries of an owner. Unfortunately, once in Nova Scotia, as was the case with the Black Loyalists, the Refugees' understanding of freedom would be severely challenged by poor economic con- 
ditions, racism, and exploitative government policies. ${ }^{24}$

The process of creating an African British North American identity began immediately after the Refugees landed in Nova Scotia and possibly as early as their escape from slavery. This early identity was partially created for them by their new environment. Despite their diverse backgrounds, they simply became unwanted black people in the eyes of the colonial government and local population. The Refugees also shared several challenges being homeless, poor, and sick. Yet, the colonial government failed to institute Lord Castlereagh's instructions concerning liberated slaves, which promised rations and support until they could care for themselves. Rather, Lieutenant Governor Sherbrooke sent some of the Refugees to the colony's interior in search of work. Others spent time at the poor house or the hospital at Melville Island, which also served as a quarantine center for the Refugees. The Refugees faced an uncertain future after their arrival as the colony fell into a postwar economic depression because the British government withdrew some of its military investments. Moreover, the Refugees' arrival coincided with the beginning of a large influx of European immigrants also in search of wage labour that the British government had confidently assumed would be available to the new African American immigrants. ${ }^{25}$

Although the colonial government wanted to use the Refugees as "Labourers for hire" as opposed to "proprietors of Land," mass European immigration and poor economic conditions forced imperial officials to place the Refugees on small ten-acre farms outside of Halifax. ${ }^{26}$ The majority of Refugees were "well pleased" with the settlement plan as the occupation of land meant the first step toward freedom. ${ }^{27}$ Unfortunately, the property given to Refugees, at the rocky and swampy settlements of Hammonds Plains and Preston (located twenty and fifteen kilometers from Halifax respectively), was too sterile and small for any family to gain a livelihood from husbandry. The Nova Scotia government recognized that new settlers needed at least 100 acres per family to engage in subsistence farming. As government officials admitted nearly 30 years later, anything less than 100 acres was a recipe for disaster. ${ }^{28}$ Indeed, most soil in Nova Scotia was so poor that substantial tracts of land had to be given to new immigrants to ensure that some of it would be usable. Moreover, local officials knew that previous settlements at Preston and Hammonds Plains had failed miserably because of the land's lack of economic potential. The government did not want to waste good land on what many thought would be another temporary settlement similar to the Black Loyalist and Jamaican Maroon debacles. Also, the colonial government gave the African American settlers tickets of location instead of freehold grants, which European settlers regularly received. Thus the Refugees obtained no more than a form of squatter's rights in that they could not sell their land and move to another part of the colony as white settlers did quite often. ${ }^{29}$

The settlement of the Refugees at Hammonds Plains and Preston marked 
some important steps in the process of creating an African British North American identity. First, the Refugees refused to be randomly settled in these rural areas. Instead, many who had known each other in the United States preferred to become neighbors in their new community. For example, many of the former slaves of Sea Island slave magnates, James Hamilton and Pierce Butler, settled together in Hammonds Plains. Accordingly, the establishment of the Sea Islanders at Hammonds Plains represented a continuing connection with cultural traits and experiences from slavery that might have seemed relatively foreign to their counterparts from the Chesapeake, such as the persistence of Gullah, the ring shout, and cooking patterns. During their initial settlement, Chesapeake Refugees generally located at Preston. Friendships forged in slavery continued in this northern frontier farming community. For example, the former slaves of Rawleigh Downman - Joseph and Robert Glasgow of Lancaster - Virginia, lived on the same farm in Preston and shared chores ranging from clearing land to building a home. Sometimes former slaves from the same county settled together in Preston. Originally from Northumberland county, but owned by different individuals, Joseph Smith, Daniel Taylor, and Peter Craney settled next to each other in section A at Preston. Several freed people from Calvert County, Maryland also became neighbors in Preston. Although Sea Island and Chesapeake Refugees settled in different areas, the process of forming communities in Preston and Hammonds Plains began the transition to Black Refugees. Indeed, Refugees from different backgrounds during slavery began to have shared experience as frontier farmers in Nova Scotia. ${ }^{30}$

During the first years of settlement (1815-1820), the Refugees tried to grow potatoes and other foodstuffs, but several crop failures and bad weather curtailed agricultural progress in both settlements and elsewhere. Chesapeake Refugees with experience in farming mixed agricultural produce had a slight advantage over their brethren from the Sea Islands who had worked in the rice swamps and cotton fields, while former slaves who had served as domestics had even less chance to become successful farmers. Nevertheless, a few families made good crops and their poorer neighbors and friends relied on these more fortunate people. In 1816, after a short period of settlement, several Refugees stayed in the homes of neighbors as they adjusted to the rigors of farming in Nova Scotia. One observer noted that some of the Refugees were "industrious and have raised a considerable quantity of Potatoes last summer, but the more helpless have fed upon them during the winter." ${ }^{31}$ The Refugees continually ran out of food and other supplies as the more fortunate households consistently helped out their struggling neighbors. The difficulties of farming in Nova Scotia struck every Refugee regardless of their place of origin or experience in the United States. ${ }^{32}$

Frontier farming in Nova Scotia was an arduous task. Many other immigrants in and around Halifax quit the land after only a few years of settlement. 
The Black Refugees at Preston and Hammonds Plains attempted to engage in successful farming, but the small size and sterility of their farms inhibited this endeavor. One Refugee told a local newspaper editor that it was "very hard to raise what we do; the rocks so many, and it takes so long to clear a very little piece of land." ${ }^{\prime 33}$ The small rectangular and rocky plots of land forced the Refugees to adopt several measures to offset poverty. First, Refugee families worked the land together, that is mother, father, sons, daughters, and extended kin jointly cultivated the land to the point that local schools complained about children missing too many classes. The poverty of the land required that all available hands help with the planting and harvesting of potatoes and other foodstuffs. As the acreage was too small to engage in multi-plot farming, or breaking the land into even smaller pieces, a core of Refugees petitioned the government for additional land. These petitions usually asserted the need for better farms, as an 1821 petition indicated, because of the "limited size and Sterile quality" of this individual's land holding. ${ }^{34}$ Interestingly, some families applied jointly for 50 additional acres outside of the settlement, while others, such as Dominic De Broker, applied for vast tracts of land to be used with 35 other heads of households. Despite the petitions and other strategies employed by the Refugees to make the land useful, the process remained difficult. Yet, many Refugees continued to attempt to become subsistence farmers. ${ }^{35}$

Given the poor land and difficulty of producing foodstuffs, it is quite remarkable that some Refugees persisted as farmers. There are several reasons for the Refugees' attachment to the land. First, many recently emancipated slaves, whether in the British Caribbean in the 1830s or the southern United States during the $1860 \mathrm{~s}$, hoped to become independent land-owning farmers. Second, it is possible that the attachment of some Refugees to their land might have resulted from the continuation of African cultures in North America. As discussed earlier, the majority of Refugees were from Virginia. Given the fact that the Igbo, an ethnic group located in what is today eastern Nigeria, maintained an important presence in early America, it is entirely possible that the Refugees' attachment to their farms was based on Igbo ideals of land as one of the most important aspects of their lives. ${ }^{36}$ As late as 1836, after several crop failures and increasing opportunities for urban work, one local government official incredulously reported that the Refugees "seem to have some attachment to the soil they have cultivated, poor and barren as it is. ${ }^{\prime 37}$ However, this attachment did not prevent these African Americans from searching for additional income in the urban labour market of Halifax. ${ }^{38}$

The problems associated with farming convinced many Refugees to turn their attention to the possibilities of urban wage labour. However, the government complicated the situation by passing a law meant to keep the Refugees from entering the urban labour market because it feared increased job competition for the new white immigrants. The Refugees ignored this law and found 
work in Halifax. As a result, the local government abandoned the law. Ignoring this law defined the Refugees' understanding of freedom in post-emancipation Halifax as the right to seek and be paid for the labour of their choice. ${ }^{39}$

The migration of Black Refugees to Halifax included both men and women. Generally, men found work in the seafaring industry, dockyards, trucking, and menial wage labour. On the other hand, women generally found work as domestics in the houses of the Halifax elite. Refugee men and women dominated the local trade in the sale of berries that they picked in rural areas and sold at the weekly market. Migrating to Halifax for jobs marked another step in the process of creating shared experience, but those Refugees who had been trained in a specific skill possessed an advantage over those who had only worked in the rice swamps or cotton fields. ${ }^{40}$

The shared experience of frontier farming and the establishment of the Refugees at Hammonds Plains and Preston forged a community unwilling to leave their new homes. The most important component of the Refugees' settlement revolved around the decision not to emigrate to Trinidad or West Africa. Local officials hoped that the Black Refugees would follow in the footsteps of the Jamaican Maroons and Black Loyalists to their ancestral homeland of Africa. Imbued with ideas about inherent black laziness and stupidity, the local government, led by Lieutenant Governor Lord Dalhousie, believed that the Black Refugees had been brought to Nova Scotia against their will. Dalhousie argued that the Refugees, "slaves by habit and nature," could never become successful settlers. ${ }^{41}$ Thus, he embarked on a series of initiatives designed to rid Nova Scotia of the Black Refugee problem. In 1817, Dalhousie attempted to enter into a treaty with the United States to send the new immigrants back to their former owners, but abandoned the proposal in the face of Refugee resistance. Not one to be discouraged, Dalhousie hoped to ship them to Sierra Leone or Trinidad. The government in the island colony of Trinidad had been actively recruiting free immigrants from Nova Scotia and elsewhere to fill gaps in the local labour market as farmers or labourers. By 1820, the Dalhousie government had secured enough money to fund an expedition there. ${ }^{42}$

The idea of settlement in Trinidad did hold out some appeal to the Black Refugees. During and after the War of 1812, hundreds of the Black Refugees' brethren had settled in Trinidad as opposed to Nova Scotia. Nova Scotia's Refugees had known some of these people and realized that moving to Trinidad might have entailed reunion with friends and possibly family members. Yet, in sharp contrast to the earlier emigration of the Black Loyalists and Jamaican Maroons, the vast majority of Black Refugees refused to leave Nova Scotia. Ultimately, only 95 individuals, out of a population numbering some 1600 , accepted the government's offer ${ }^{43}$ The Trinidad settlers were mostly from Hammonds Plains and had relatively small families. Once in Trinidad, they settled in Naparima and did quite well as farmers, producing corn, rice, and rais- 
ing poultry and other foodstuffs for community consumption. ${ }^{44}$ News of this successful settlement and the possibilities of free black relocation in Trinidad eventually reached the shores of Boston, prompting anti-slavery activist James G. Barbadoes to write the Nova Scotia government in the late 1830s to ask for one of Her Majesty's ships in order to gather interest in the resettlement of black Bostonians. Not much came of this letter, because Barbadoes remained in Boston, but certainly the linkages between Halifax and the West Indies did not escape the notice of blacks in Massachusetts. ${ }^{45}$

An important question remains: Why did the vast majority of Black Refugees refuse the offer to migrate to Trinidad? In 1823, Lieutenant Governor James Kempt stated that "these people entertain so great a fear of slavery that no persuasions can induce them to remove to any place where slavery exists." ${ }^{46}$ Yet, there were other reasons behind the Refugees' refusal to leave the colony. They had started the process of becoming a distinct group of African British North Americans through the creation of friendships, families, and shared experience with frontier farming. In terms of the creation of families, at Preston and Hammonds Plains, in 1815 and 1820 respectively, over 90 percent of identifiable households contained two parents and several children. Many of these families had been formed in Nova Scotia. The Refugees, on their small farms, had also established community bonds that meant more to them than the advantages that might be found in Trinidad. Moreover, black religious leaders depicted the proposed migration as a scheme to destroy the community and sell the Refugees into slavery. The Refugees could have reestablished friendships left behind in the Chesapeake or the Sea Islands if they had gone to Trinidad, yet they consciously decided to maintain the distinct communities they had formed in Nova Scotia. ${ }^{47}$

Despite the Refugees' clear rejection of the Trinidad plan, the government appealed in 1825 to "the more intelligent Blacks in Nova Scotia," to reconsider their determination to remain in Preston and Hammonds Plains. ${ }^{48}$ Again, the Refugees had no interest in a scheme they regarded as inimical to community interests. The colonial government, however, could not give up the idea of ridding the colony of blacks. The offer was renewed in the mid-1830s because local officials feared an influx of new black immigrants, due to Britain's abolition of slavery in 1834. Only half of the blacks at Hammonds Plains attended a meeting designed to convey "favourable" information about resettlement in the West Indies, but not one person agreed to migrate to Trinidad. Local officials considered this refusal to leave Nova Scotia to be based on two reasons. Firstly, it was said that the Refugees entertained a "foolish and indefinite fear" that the government would sell them into slavery. ${ }^{49}$ Secondly, several fortunate families who made good crops every year refused to leave and the majority of the community did not want to migrate without them. ${ }^{50}$ In Preston, the government found a similar reaction to its proposal. This rejection of the Trinidad 
scheme signified the Refugees' final decision to remain in Nova Scotia as a distinct group of African British North Americans.

The Refugees determination to remain in Nova Scotia highlights their connections to questions of identity within the Black Atlantic. The term identity is problematic and has been the source of much scholarly interest. In this paper, it is used to discuss the commonality of people, expressions of shared experience, and self or group understanding of social location. This does not mean that shared experience inevitably leads to unity, but rather that the Refugee experience in Nova Scotia did create conditions for an identity or consciousness that expressed the concerns of many of the community. The identity developed by the Black Refugees had several components that included recognition of their double dispersal from Africa and the United States, attachment to their ancestral homeland of Africa, struggle with slavery and freedom, memories of slavery, promotion of abolitionism, resistance to hostile whites, and claims for citizenship within their new political home. The Refugees' previous slave identities slowly developed into the identity of African British North American, but it is important to note that their blackness was not the Refugees' only connection. Instead, this emerging identity rested on struggles for freedom, political inclusion, shared experience, and location within the British Empire. It had transnational and Black Atlantic foundations, as memories of slavery and emancipation focused on celebrating the independence of blacks in the West Indies or challenging the condition of African Americans in the southern United States. ${ }^{51}$

The Refugees' heightened consciousness came about during the 1830s and 1840s through the development of community institutions such as the African Baptist and Methodist churches along with improvement and political organizations. The most prominent of these organizations, the African Friendly Society and the African Abolition Society, served as centers of anti-slavery activity and public celebrations. These public celebrations and political agitation provide our best insight into the process of constructing the political side of their African British North American identity. ${ }^{52}$

The transformation of African American identities in Nova Scotia is especially intriguing because of the colony's geographic location on the American frontier, while still being firmly embedded within the politics of the British Empire. Unlike the free black communities in Boston or Philadelphia, which were clearly located on the American side of the Atlantic, the Black Refugees in Halifax occupied a space where interactions between America and Great Britain had an everyday dynamic. Similar to blacks in the northern United States, the Black Refugees recalled their distant homeland by naming various organizations "African." The most significant difference between free blacks in Nova Scotia and their counterparts in the United States was the Refugees' consciousness of their connection with Great Britain. The Black Refugees saw 
themselves as British subjects partially because they had been freed by the Royal Navy during the War of 1812 . As early as 1818 , some Black Refugees drew a clear distinction between their rights in the British Empire as opposed to their status as American slaves. For example, after a dispute between her family and a group of white hunters, Maria Fuller exclaimed that she could do what she wanted because "we are not now in the U. States." to the government also expressed a "firm" attachment to the British Crown. ${ }^{54}$ These early examples only set the stage for public displays of loyalty to Great Britain, which illustrated the Refugees' claim to citizenship in Nova Scotia and the empire..$^{5 s}$

During the late 1830s and early 1840 s, the Black Refugees participated in several public displays of loyalty that attached African liberty, equal rights, and freedom to the British Empire. In 1838, the local black community participated in the celebrations for Victoria's coronation. In this parade, the Black Refugees, led by the African Friendly Society, carved out a place in the public domain to express this developing identity. As the former slaves marched down the main streets in Halifax, they held banners affirming their loyalty to Great Britain that read "Victoria and Freedom." Local newspapers conceded that the black population had "claimed the right ... of joining their fellow citizens" in honoring the coronation of the new Queen. ${ }^{56}$ In 1846, the Charitable African Society participated in the farewell to outgoing Governor Lord Falkland. Led by the Charitable African Society local blacks expressed their "loyalty and affection" to Queen Victoria and reasserted that blacks were "true, loyal and grateful subjects of Her Royal Majesty." ${ }^{77}$

Ironically, the Refugees illustrated a localized version of the slave mask during this ceremony to celebrate the end of slavery. As local politicians attempted to restructure the colonial government, the Liberals and Tories engaged in constant disputes over the colony's future that took center stage in nearly every local newspaper. Although the Refugees understood this situation quite clearly, they claimed not to know what "the gentleman have been quarreling about" since all subjects of the crown in Nova Scotia were "free and enjoy equal rights." $" 58$ This public display of the knowledge of their place was good politics because it made blacks seem naïve to the local political situation and as a result, both parties, Liberals and Tories, would fight for black votes during the election of 1847.

As historian David Sutherland notes, blacks had been involved in local politics since the $1830 \mathrm{~s}^{59}$ Yet, the 1840 s marked a time of increased participation as both parties fought for control of Nova Scotia's future. The Liberals hoped to overthrow what they considered the entrenched Tory elite. The changes to the political system in British North America had been encouraged as a result of reforms that flowed across the Atlantic from Great Britain to Nova Scotia and the Rebellions in Upper and Lower Canada during the late 1830s. In 1840 
and 1843, many blacks in the Halifax area supported the Liberals because their leader, Joseph Howe, had long been concerned with improving the position of blacks in local society. As early as 1832 , Howe had called for more black people to become involved in the colonial mainstream. ${ }^{60}$ During the elections of 1840, African Nova Scotians played a public role that affirmed their status as British subjects:

Yesterday the Court was crowded long before the hour appointed for commencing to register the votes. A rich display was formed by the coloured folks from Preston, who came over in a steamer decorated with flags.... The African gentry had formed themselves into a procession, and on landing marched with flying colours, through part of Water and Hollis street ... to the Court House ... and took complete possession of the passage for the entree and exit of the voters. ${ }^{61}$

After winning the elections in 1840 , Howe changed the Refugees' tickets of location in Preston to freehold grants, which won him the support of the black community.

However, in 1847, the political situation had changed. After a dispute with the government a few years earlier, Howe resigned his position and hoped to replace the governing party in the upcoming election. The Liberals saw an opportunity to gain the support of Halifax's rapidly increasing Irish Catholic population while the Tories, who drew support from more traditional elements of the local population hoped to broaden their appeal by appointing the black leader Richard Preston to their political campaign. Reverend Preston's position in the African Baptist church resulted in some, but certainly not all, Black Refugees supporting the Conservatives. Preston and the Conservatives accused the Liberals of attempting to break the British link and align Nova Scotia with the United States. As the vote promised to be close, the Liberals and Conservatives courted the black vote on numerous occasions, including rallies at Preston and Hammonds Plains in the spring and summer of 1847. In Preston, Howe found much support from the local community. Black supporters of Howe derided the governing party, outlined Liberal support of the Refugees, and declared that "we value too our rights as British subjects ... particularly the Elective Franchise." ${ }^{\prime}$ Howe also reminded the gathering that the Tories had connections with American slavery because of their mercantile interests. At Hammonds Plains, the Liberal party did not find nearly as much support. Howe hoped to address the black population, but instead found himself surrounded by Conservatives waving Tory flags and holding signs linking black freedom to Queen Victoria. Blows were almost exchanged between the supporters of the Conservatives and Liberals, but eventually Howe addressed a portion of the Hammonds Plains blacks and departed after leading three cheers for the Liberal party and the Queen. ${ }^{63}$ 
These events set the stage for nomination day in Nova Scotia. Although not all blacks could vote, the opposing parties usually gathered supporters to serve as voter intimidators and cheering sections. The Liberals drew support from the city's increasing Irish Catholic population, while the Conservatives drew support from some members of the black population. The opposing sides gathered in prearranged areas, but after the consumption of alcohol, a fight broke out between the black Conservatives and the mostly white Liberals. Although several people were injured, no one died. ${ }^{64}$ Liberal newspapers blamed the Tories for bringing black people to the event, even though many met the qualifications to vote, while ignoring the fact that most Irish participants could not vote because they owned no property. As it turned out, the Liberals won the election and the Conservatives soon abandoned their support of people of African descent. ${ }^{65}$

The struggles of the Black Refugees for political inclusion based on ideas of British justice and benevolence contrast with the findings of American historian Patrick Rael for black northerners during the Antebellum period. Some of the black northern elite of Rael's study expressed their goals and aspirations in American values and ideas. In contrast, the Black Refugees couched their struggle for equal political treatment by claiming British citizenship. Their expression of Britishness attempted to make this concept inclusive with the Refugees' racial identity. As black northerners, according to Rael, played an important role in the construction of an American nationality, the same can be said for the Black Refugees in helping to construct a British North American nationality grounded in the idea that colonials were the most loyal of Britain's many subjects. The Black Refugees' political identity, similar to the wider British North American consciousness, was partially based around the ideal of not being American. Thus, the Refugees' presence in public displays of loyalty during the Queen's coronation or at political contests helped the wider public define themselves against what they thought were American ideals, such as vicious racism, barring blacks from the franchise, and the continued enslavement of millions of people. In addition to the Refugees' emerging political identity, they also developed a cultural consciousness that worked its way through the tensions of being black and North American. ${ }^{66}$

W. E. B. Du Bois' formulation of African Americans' double consciousness, and Paul Gilroy's later elaboration on the subject, raise important questions about people of African descent, particularly in regard to a sense of self and group perception. As Gilroy notes, the Black Atlantic transcended national borders and the Black Refugees' cultural and social identity engaged with issues prevalent in other communities throughout the Americas. For example, the Refugee identity was based on the issues of slavery, emancipation, racial pride and improvement, and an attachment to their ancestral homeland of Africa. The development of the African Abolition Society provided an outlet 
for cultural expressions that formed the bedrock of the Refugees' identity. ${ }^{67}$

The creation of the African Abolition Society in 1846 marked an interesting component of African British North American identity. It combined elements of the Refugees' American background, British connection, and African origins. The Refugees maintained an anti-American attitude because they recalled their experience as American slaves and it dictated many of their concerns about communal security and the fate of black people in the Republic. American slavery had robbed many Black Refugees of family members and their anger over this and other injustices made them accept the difficult conditions of Nova Scotia. In 1844, one Refugee woman from the Chesapeake explained the difference between slavery in America and freedom in Nova Scotia thusly:

I'll tell you what slavery is like: They won't let us marry, but for all that we like our men the same as white women do, and we like our children the same as white women; but they take away our men and take our children when they are grown, and take them to New Orleans ... and if we were to cry till our heart break, they mock us.... I'll live on taters and salt [a reference to life in Nova Scotia], and help fight myself till I die, before I'll be a slave again. ${ }^{68}$

The Abolition society held a meeting where one member proclaimed a willingness "to embark for Yankee land and give the oppressors musket balls for breakfast, cannon balls for dinner, and bomb shells for tea." ${ }^{\prime 69}$ Despite their disdain for the Peculiar Institution, the Refugees remained keenly aware of events that affected former friends, family members, and the general African American population. For example, in 1850 , the Abolition society held a meeting to discuss the condition of their "Brethren, who are at this time under the hand of oppression in the United States of America ... also the Committee intend passing several resolutions touching the Fugitive Slave Law, recently passed in the United States." and subsequent migration to Nova Scotia. Instead, it became part of their collective consciousness as recently emancipated slaves.

During the late 1840 s and 1850 s, the society annually celebrated the abolition of slavery in the West Indies. This indicated the Refugees' identification with events in the British Empire and relations with blacks throughout the Americas. At these meetings, the society usually made several toasts and these toasts included three important components of their identity. In 1850, the Refugees reserved the first toast for "AFRICA, the land of our Forefathers, may she ever stand in a united Body, and at last vanquish her foes." edgement of the black community's attachment to their ancestral land was followed by several toasts to British officials. Finally, the group stated that it hoped to "never fail in promoting the cause of her poor and oppressed people, 
from every nation beneath the Sun." Interestingly, five years later, the group focused the success of abolition within a British framework by praising Wilberforce and Clarkson as "the noble advocates for African liberty." Moreover, they hoped for the success of abolition societies in "Canada, Bermuda, and all the West India islands." ${ }^{\prime 2}$ Clearly, the movement of the Refugees from slavery to emancipation resulted in their identification with the currents of abolition in the British world.

The Black Refugees constructed an identity that added additional components to Du Bois' theory of double consciousness. The Black Refugees created an identity that wove British, American, North American, Nova Scotian, and African elements into a cohesive consciousness. This identity was replete with several tensions that adapted certain elements of the dominant British culture, while remembering their own history of dispersal from Africa, migration, and enslavement. The Refugees were extremely conscious of their voluntary migration from the United States and its cultural, economic, and social implications. After years of struggling to adjust to the social and economic context of Nova Scotia, the Refugees' identity emerged as based in notions of Britishness underlined by ideas of racial identity.

The Black Refugees identification of their freedom with Great Britain slowly took precedent over former American identities. The shared experience of settlement, frontier farming, community formation, and remaining in Nova Scotia created the foundation for a new consciousness that was developed through public proclamations of loyalty to the Queen. Moreover, as none of the Black Refugees had been able to exercise the franchise in the United States, the opportunity to do so in Nova Scotia underlined another important difference from their lives as slaves. The Black Refugees used political participation and their connection with what they termed British freedom to forge a new consciousness as African British North Americans. The Refugees' freedom struggles in Nova Scotia mirrored some of the challenges facing free African Americans in the northern United States, but their consciousness differed from Afro-Yankees because of their open anti-Americanism and pro-British attitudes. Although the process of becoming African British North Americans continued after 1850 , the foundations of a distinct society had been successfully forged.

\section{Notes}

${ }^{1}$ Morning Herald (Halifax), 31 December 1841.

${ }^{2}$ Novascotian (Halifax), 9 January 1843.

${ }^{3}$ British Colonist (Halifax), 25 July 1850.

${ }^{4}$ Robert L. Harris, "Coming of Age," cited in Robin D. G. Kelley, "“But a Local Phase 
of a World Problem': Black History's Global Vision, 1883-1950," Journal of American History 86 (1999): 1045.

${ }^{5}$ Kelley, "'But a Local Phase of a World Problem," 1045-77; Earl Lewis, "To Turn as on a Pivot: Writing African Americans into a History of Overlapping Diasporas," American Historical Review 100 (June 1995): 765-87.

${ }^{6}$ There has only been one small but important treatment of black identity in eighteenthand nineteenth-century Nova Scotia: James W. St. G. Walker, The Black Identity in Nova Scotia: Community and Institutions in Historical Perspective (Dartmouth: Black Cultural Centre for Nova Scotia, 1985). Studies about the Black Refugees understandably and ably focus on racism, race relations, economic struggle, and social development; see C. B. Fergusson, A Documentary Study of the Establishment of the Negroes in Nova Scotia between the War of 1812 and the Winning of Responsible Government (Halifax: Public Archives of Nova Scotia, 1948); Robin W. Winks, The Blacks in Canada: A History (New Haven: Yale University Press, 1971), 114-41; James W. St. G. Walker, "The Establishment of a Free Black Community in Nova Scotia," in The African Diaspora: Interpretive Essays, eds. Martin Kilson and Robert Rotberg (Cambridge: Harvard University Press, 1976); John Grant, The Immigration and Settlement of the Black Refugees of the War of 1812 in Nova Scotia and New Brunswick (Hantsport: Lancelot Press, 1990).

${ }^{7}$ John Johnston, "Research Note: Mathieu Da Costa along the Coasts of Nova Scotia: Some Possibilities," Journal of the Royal Nova Scotia Historical Society 4 (2001): 15264.

${ }^{8}$ Kenneth Donovan, "Slaves in Ile Royale," French Colonial History 5 (2004): 25-42, 29.

${ }^{9}$ T. W. Smith, "The Slave in Canada," Collections of the Nova Scotia Historical Society 10 (1899), 10; 1767 Nova Scotia Census, vol. 443, doc. 1, RG 1, Nova Scotia Archives and Records Management, Halifax, Nova Scotia (hereafter NSARM); Letter from Governor Cornwallis about Captain Bloss and His Slaves, 22 September 1750, vol. 35, doc. 25, RG 1, Governor's Letter Book, NSARM; Gazette (Halifax), 15 May 1752; Gary Hartlen, "Bound for Nova Scotia: Slaves in the Planter Migration, 1759-1800," in Making Adjustments: Change and Continuity in Planter Nova Scotia, 1759-1800, ed. Margaret Conrad (Fredericton: Acadiensis Press, 1991).

${ }^{10}$ Walker, "Free Black," 209-10.

${ }^{11}$ Clarkson's Mission to America, 1791-1792, ed. Charles Bruce Fergusson (Halifax: Public Archives of Nova Scotia, 1971), 46.

${ }^{12}$ Book of Negroes, vol. 423, RG 1, Negro and Maroon Settlements, NSARM; Sylvia Frey, Water from the Rock: Black Resistance in a Revolutionary Age (Princeton: Princeton University Press, 1991); James W. St. G. Walker, The Black Loyalists: The Search for a Promised Land in Nova Scotia and Sierra Leone, 1783-1870 (London: Longman and Dalhousie University Press, 1976); Ann G. Condon, "1783-1800: Loyalist Arrival, Acadian Return, Imperial Reform," in The Atlantic Region to Confederation: A History, eds. Phillip A. Buckner and John G. Reid (Toronto: University of Toronto Press, 
1994), 184-209; Wentworth's Instructions for the Jamaican Maroons, 29 June 1797, vol. 419, doc. 19, RG 1, Negro and Maroon Settlements, NSARM; Lennox Picart, "The Trelawny Maroons and Sir John Wentworth: The Struggle to Maintain Their Culture," Collections of the Royal Nova Scotia Historical Society 44 (1996): 165-87; Allister Hines, "Deportees in Nova Scotia: The Jamaican Maroons, 1796-1800," in Working Slavery, Pricing Freedom: Perspectives from the Caribbean, Africa, and the African Diaspora, ed. Verene Shepherd (New York: Palgrave Macmillan, 2002), 206-22; John Grant, The Maroons in Nova Scotia (Halifax: Formac, 2002).

${ }^{13}$ House of Assembly, 1 April 1815, vol. 305, doc. 3, RG 1, Journal of the House of Assembly, NSARM.

${ }^{14}$ Chamberlain to Morris, 11 November 1815, vol. 419, doc. 41, RG 1, Negro and Maroon Settlements, NSARM.

${ }^{15}$ Mary Jane Katzmann (Mrs. William Lawson), History of the Townships of Dartmouth, Preston, and Lawrencetown (Halifax: Morton, 1893), 187-88.

${ }^{16}$ A small number of Refugees were from South Carolina, coastal Georgia, Florida, and Louisiana.

${ }^{17}$ Ira Berlin, "Time, Space, and the Evolution of Afro-American Society on British Mainland North America," American Historical Review 85 (February 1980): 54.

${ }^{18}$ Documents Furnished By The British Government Under The Convention of St. Petersburg And Bayly's List of Slaves And Of Public And Private Property, Remaining On Tangier Island And On Board H.B.M. Ships Of War After The Ratification Of The Treaty of Ghent (Washington: Gales and Seaton, 1827); Claims for Slaves in Virginia, MG 15, Ethnic Groups: Blacks, NSARM; Thomas Newell and Thomas Spalding, A list of the negroes in possession of the British forces in the state of Georgia (16 March 1815), MG 15, Ethnic Groups: Blacks, NSARM; On slavery in the Chesapeake and Lowcountry, see Ira Berlin, Many Thousands Gone: The First Two Centuries of Slavery in North America (Cambridge: Harvard University Press, 1998), 256-89; Philip D. Morgan, Slave Counterpoint: Black Culture in the Eighteenth-Century Chesapeake and Lowcountry (Chapel Hill: University of North Carolina Press, 1998); Ira Berlin and Ronald Hoffman, eds., Slavery and Freedom in the Age of the American Revolution (Charlottesville: University Press of Virginia, 1983); Mary Turner, ed., From Chattel Slaves to Wage Slaves: The Dynamics of Labour Bargaining in the Americas (Bloomington: Indiana University Press 1995); Allan Kulikoff, Tobacco and Slaves: The Development of Southern Cultures in the Chesapeake, 1680-1800 (Chapel Hill: University of North Carolina Press, 1986); William Dusinberre, Them Dark Days: Slavery in the American Rice Swamps (New York: Oxford University Press, 1996); Julia Floyd Smith, Slavery and Rice Culture in Low Country Georgia, 1750-1860 (Knoxville: University of Tennessee Press, 1985).

${ }^{19}$ National Intelligencer (Washington DC), 1 May 1813; Niles Weekly Register (Baltimore), 22 May 1813; Admiral Cockburn to Admiral Cochrane, 25 June \& 24 July 1814, Papers of Admiral Sir Alexander Forrester Inglis Cochrane, 1813-1815 (Florida State University Libraries, Tallahassee, Florida); Shipping Log, HMS Junon, September 
1813, vol. 420, doc. 1, RG 1, Negro and Maroon Settlements, NSARM; Frank Cassell, "Slaves of the Chesapeake Bay Area and The War of 1812," Journal of Negro History 57 (April 1972): 144-55; John Grant, "Black Immigrants into Nova Scotia, 1776-1815," Journal of Negro History 58 (July 1973): 253-70; W. A. Spray, "The Settlement of the Black Refugees in New Brunswick, 1815-1836," Acadiensis 6 (Spring 1977): 15-36; Mary Bullard, Black Liberation on Cumberland Island in 1815 (South Dartmouth: $\mathrm{M}$. R. Bullard, 1983), 62-80; Christopher T. George, "Mirage of Freedom: African Americans in the War of 1812," Maryland Historical Magazine 91 (Winter 1996): 42750; John Weiss, Free Black American Settlers in Trinidad, 1815-16 (London: McNish and Weiss, 1995); Harvey Amani Whitfield, "We Can Do As We Like Here': An Analysis of Self Assertion and Agency Among Black Refugees in Halifax, Nova Scotia, 1813-1821," Acadiensis (Autumn 2002): 29-49.

${ }^{20}$ The best source for slave occupations is "Claims for Slaves in Virginia," Misc. Blacks War of 1812, MG 15, Ethnic Groups: Blacks; NSARM; this document lists over 150 occupations for a list of over 1200 slaves. Common occupations for women included: servant, spinner, cook, and weaver. The occupations of male slaves included: carpenter, sawyer, field slave, blacksmith, and house servant; on slaves and market trading, see Betty Wood, "'Never on a Sunday?' Slavery and the Sabbath in Lowcountry Georgia, 1750-1830," in From Chattel Slaves to Wage Slaves: The Dynamics of Labour Bargaining in the Americas, ed. Mary Turner (Bloomington: Indiana University Press, 1995); Robert Olwell, "Loose, Idle, and Disorderly': Slave Women in the EighteenthCentury Charleston Marketplace," in More Than Chattel: Black Women and Slavery in the Americas, eds. David Gasper and Darlene Clark Hine (Bloomington: Indiana University Press, 1996), 97-110; Morgan, Slave Counterpoint, 372-73.

${ }^{21}$ Charles Ball, Slavery in the United States: A Narrative of the Life and Adventures of Charles Ball (1837; rep., New York: Negro Universities Press, 1969), 472.

${ }^{22}$ G.R. Gleig, A Narrative of the Campaigns of the British Army at Washington and New Orleans under Generals Ross, Pakenham, and Lambert, in the years 1814 and 1815 (London: J. Murray, 1821), 144.

${ }^{23}$ Morning Chronicle (Halifax), 7 October 1889.

${ }^{24}$ List of slaves allowed to Virginia, Maryland, etc. at Georgia Average, Misc., Blacks War of 1812, MG 15, Ethnic Groups: Blacks; NSARM; in this document 16 marriages were listed and over 50 percent were separated and reunited in Halifax.

${ }^{25}$ Acadian Recorder (Halifax), 23 December 1815; Coleman's Report, 16 April 1816, vol. 419, doc. 76, RG 1, Negro and Maroon Settlements, NSARM; Dalhousie to Bathurst, 29 December 1816, vol. 112, pp. 6-9, RG 1, Lieutenant Governor's Letter Book, NSARM; Cochrane to Sherbrooke, 5 October 1814, vol. 111, doc. 110, RG 1, Lieutenant Governor's Letter Book, NSARM; Sherbrooke to the House of Assembly, 24 February 1815, vol. 288, doc. 101, RG 1, Journal of the House of Assembly, NSARM; Castlereagh to Prevost, 10 April 1808, vol. 420, doc. 9, RG 1, Negro and Maroon Settlements, NSARM; on the postwar economic depression and mass immigration, see David A. Sutherland, "1810-1820: War and Peace," in The Atlantic Region to 
Confederation: A History, eds. Phillip A. Buckner and John G. Reid (Toronto: University of Toronto Press, 1994), 234-60; J. S. Martell, Immigration to and Emigration From Nova Scotia, 1815-1838 (Halifax: Public Archives of Nova Scotia, 1942); on the problems facing the new settlers see the important work of Grant, Immigration and Settlement.

${ }^{26}$ Glenelg to Campbell, 25 October 1837 , vol. 422, doc. 50, RG 1, Negro and Maroon Settlements, NSARM.

${ }^{27}$ Bathurst to Sherbrooke, 13 June 1815, vol. 63, doc. 12, RG 1, Dispatches from the Secretary of State to the Lieutenant Governor, NSARM; Morris to Sherbrooke, 6 September 1815, vol. 420, doc. 76, RG 1, Negro and Maroon Settlements, NSARM.

${ }^{28}$ In Council, 11 March 1841, Box-Crown Lands-Peninsula of Halifax-1840-1845, vol. 31, doc. 124, RG 20 C, Land Papers, NSARM.

${ }^{29}$ The poverty of the soil at Hammonds Plains and Preston was well known throughout the colony's population, see Memorial of John Chamberlain, et al., 8 June $1838 \ldots$ Reside in the neighbourhood of the people of colour settled in Preston, vol. 422, doc. 49, RG 1, Negro and Maroon Settlements, NSARM; Acadian Recorder (Halifax), 21 February 1824; Morning Chronicle (Halifax), 29 October 1841; In Council, 11 March 1841, Box-Crown Lands-Peninsula of Halifax-1840-1845, vol. 31, doc. 124, RG 20 C, Land Papers, NSARM; on the failure of previous settlements see, Chamberlain to Morris, 11 November 1815, vol. 419, doc. 41, RG 1, Negro and Maroon Settlements, NSARM; Dorothy Evans, Hammonds Plains: The First 100 Years (Halifax: Bounty Print, 1993); Walker, "Free Black," 227-29; Fergusson, Documentary Study, 12-13.

${ }^{30}$ Return of the Black American Refugees residing at Hammonds Plains, vol. 422, doc. 19, RG 1, Negro and Maroon Settlements, NSARM; "Bayly's List of Slaves," in British Government Documents, 104-09; Report of the Inspection of Preston Lots, August 1818, vol. 419, doc. 90, RG 1, Negro and Maroon Settlements, NSARM.

${ }^{31}$ Scott to Kempt, 19 March 1821, vol. 422, doc. 28, RG 1, Negro and Maroon Settlements, NSARM.

${ }^{32}$ Harvey A. Whitfield, "Black American Refugees in Nova Scotia, 1813-1840," (PhD diss., Dalhousie University, 2003), 135-36; Report of Lands Cleared by People of Colour in Preston, May 9, 1816, vol. 421, doc. 3, RG 1, Negro and Maroon Settlements, NSARM.

${ }^{33}$ Morning Post (Halifax), 16 January 1841.

${ }^{34}$ Petition of Levin Winder, 1821, Land Papers, RG 20, Series A, NSARM.

${ }^{35}$ Examples of group petitioning include: Petition of Jeremiah Gardner and Jacob Allen, 1822, RG 20, Series A, Land Papers, NSARM; Petition of Henry Lee Sr., Henry Lee Jr., Winslow Sparkes, and William Bunday, 1820, Series A, Land Papers, NSARM; Dominic De Broker and 35 others, the Nova Scotia Archives and Records Management has lost this petition, we must rely on the account of it in the card catalogue and Fergusson, Documentary, 51-52.

${ }^{36}$ Michael A. Gomez, Exchanging Our Country Marks: The Transformation of African Identities in the Colonial and Antebellum South (Chapel Hill: University of North 
Carolina Press, 1998), 128-29.

${ }^{37}$ Lowe to James, 7 June 1836, House of Assembly, Appendix 9, 1837, Journal of the House of Assembly, NSARM.

${ }^{38}$ The question of "Igbo" identities and characteristics in North America has been disputed by historians; see David Northrup, "Igbo and Myth Igbo: Culture and Ethnicity in the Atlantic World, 1600-1850" Slavery and Abolition 21 (2000): 1-20; Douglas B. Chambers, "The Significance of Igbo in the Bight of Biafara Slave Trade: A Rejoinder to Northrup's 'Myth Igbo,"' Slavery and Abolition 23 (2002): 101-20; Hilary Beckles and Verene Shepherd, Caribbean Freedom: Economy and Society from Emancipation to the Present (Princeton: Markus Wiener, 1996); Michael Craton, Empire, Enslavement, and Freedom in the Caribbean (Princeton: Markus Wiener, 1997); Leon Litwack, Been in the Storm So Long: The Aftermath of Slavery (New York: Knopf, 1979).

${ }^{39}$ His Majesty's Council to Dalhousie, 29 November 1816, vol. 421, doc. 37, RG 1, NSARM.

${ }^{40}$ Coleman to Sabatier, 23 March 1815, vol. 21, doc. 84, RG 1, Records of the Legislative Assembly, NSARM; Winks, Blacks, 114-41; His Majesty's Council to Dalhousie, 29 November 1816, vol. 421, doc. 37, RG 1, Negro and Maroon Settlements, NSARM; On African Nova Scotian employment patterns, see 1827 and 1838 Nova Scotia Census, RG 12, NSARM; Acadian Recorder (Halifax), 4 January 1817; on blacks as seafarers, see The Petition of the Reverend Robert Willis, 27 January 1840, vol. 296, doc. 48, RG 5 P, School Petitions, NSARM; Acadian Recorder (Halifax), 29 August 1818; W. S. Moorsom, Letters from Nova Scotia: Comprising Sketches of a Young Country (London: H. Colburn \& R. Bentley 1830), 126.

${ }^{41}$ Dalhousie to Bathurst, 29 December 1816, vol. 112, pp. 6-9, RG 1, Lieutenant Governor's Letter Book, NSARM.

${ }^{42}$ Dalhousie to Bathurst, 16 May 1817, vol. 112, pp. 23-26, RG 1, Lieutenant Governor's Letter Book, NSARM; John N. Grant, "The 1821 Emigration of Black Nova Scotians to Trinidad," Nova Scotia Historical Quarterly 2 (September 1972): 283-92.

${ }^{43}$ Kempt to Harrison, 20 January 1822 [1821], vol. 113, doc. 35, RG 1, Lieutenant Governor's Letter Book, NSARM; Those who wish to go to Trinidad, vol. 422, doc. 20, RG 1, Negro and Maroon Settlements, NSARM.

${ }^{44}$ Fergusson, Documentary, 37.

${ }^{45}$ Weiss, Black Settlers; Barbadoes to George, 21 November 1839, vol. 422, doc. 54, RG 1, Negro and Maroon Settlements, NSARM.

${ }^{46}$ Kempt to Bathurst, 16 October 1823, Colonial Office 217/142, Colonial Office Papers, NSARM.

${ }^{47}$ Return of the Black American Refugees residing at Hammonds Plains, 1820, vol. 422, doc. 19, Negro and Maroon Settlements, NSARM; Report of People off [sic] Colour at, and about Preston, 30 September 1815, Public Archives of Nova Scotia-Box-Halifax County Land Grants, 1787-1835, doc. 169, RG 20 Series C, Land Papers, NSARM; Kempt to Horton, 4 May 1825, Colonial Office 217/144, Colonial Office Papers, NSARM. 
${ }^{48}$ Kempt to Horton, 7 June 1825, Colonial Office 217/144, Colonial Office Papers, NSARM.

${ }^{49}$ Grey to James, 11 May 1836, House of Assembly, Appendix 9, 1837, Journal of the House of Assembly, NSARM.

${ }^{50}$ Lowe to James, 7 June 1836, House of Assembly, Appendix 9, 1837, Journal of the House of Assembly, NSARM.

${ }^{51}$ Stuart Hall, "Cultural Identity and Diaspora," in Identity, Community, Culture, Difference, ed. Jonathan Rutherford (London: Lawrence \& Wishart, 1990), 222-37; Stuart Hall and Paul Du Gay, eds., Questions of Cultural Identity (London: Sage Publications, 1996); Frederick Cooper and Rogers Brubaker, "Beyond Identity," Theory and Society 29 (2000): 1-47.

${ }^{52}$ On the development of the African Baptist church, see Peter E. McKerrow, A Brief History of the Coloured Baptists in Nova Scotia, 1783-1895 (1895; reprint, Halifax: Afro Nova Scotian Enterprises, 1895); On the African Methodist church, see Sun (Halifax), 19 August 1846; Petition of Citizens of Color, vol. 45, doc. 12, RG 5 series P, NSARM Belchers Farmer's Almanack, 1848-1860; Novascotian (Halifax), 10 and 24 August 1846.

${ }^{53}$ Acadian Recorder (Halifax), 4 July 1818.

${ }^{54}$ Petition of James Barron, RG 20 C, Land Papers, NSARM.

ss James Oliver Horton and Lois E. Horton, Black Bostonians: Family Life and Community Struggle in the Antebellum North (1979; rep., New York: Holmes and Meier, 1999); Gary B. Nash, Forging Freedom: The Formation of Philadelphia's Black Community, 1720-1840 (Cambridge: Harvard University Press, 1988); James Oliver Horton and Lois E. Horton, In Hope of Liberty: Culture, Community, and Protest Among Northern Free Blacks, 1700-1860 (New York: Oxford University Press, 1997); Patrick Rael, Black Identity and Black Protest in the Antebellum North (Chapel Hill: University of North Carolina Press, 2002).

${ }^{56}$ Acadian Recorder (Halifax), 2 July 1838.

${ }^{57}$ Novascotian (Halifax), 10 August 1846.

${ }^{58} \mathrm{Ibid}$.

${ }_{59}$ David A. Sutherland, "Race Relations in Halifax, Nova Scotia, During the MidVictorian Quest for Reform," Journal of the Canadian Historical Association 7 (1996): $35-54$.

${ }^{60}$ Novascotian (Halifax), 27 August 1832.

${ }^{61}$ Morning Post (Halifax), 5 November 1840.

${ }^{62}$ Novascotian (Halifax), 10 May 1847.

${ }^{63}$ Sun (Halifax), 28 July 1847; Sutherland, "Race Relations," 44-48.

${ }^{64}$ Sun (Halifax), 30 July 1847.

${ }^{65}$ The best analysis of this event is Sutherland, "Race Relations," 46-47.

${ }^{66}$ Rael, Black Identity, chapters 2 and 3.

${ }^{67}$ Paul Gilroy, The Black Atlantic: Modernity and Double Consciousness (Cambridge: Harvard University Press, 1993). 
${ }^{68}$ Morning Chronicle (Halifax), 9 July 1844.

${ }^{69}$ Novascotian (Halifax), 21 October 1850.

${ }^{\pi}$ British Colonist (Halifax), 31 October 1850.

"British Colonist (Halifax), 6 August 1850.

${ }^{n}$ British Colonist (Halifax), 4 August 1855. 